\title{
Impact of deoxynivalenol (DON) contaminated feed on intestinal integrity and immune response in swine
}

\author{
Martin Lessard a,b,*, Christian Savard c, Karine Deschene a, Karoline Lauzon a , \\ Vicente A. Pinilla ${ }^{c}$, Carl A. Gagnon b,c, Jérôme Lapointe ${ }^{a}$, Frédéric Guay b,d, Younès Chorfi b,e \\ a Dairy and Swine Research and Development Centre, Agriculture and Agri-Food Canada, 2000 College Street, Sherbrooke, QC, Canada \\ ${ }^{\mathrm{b}}$ Swine and Poultry Infectious Diseases Research Center (CRIPA), Faculté de médecine vétérinaire, Université de Montréal, Saint-Hyacinthe, QC, Canada \\ ${ }^{\mathrm{c}}$ Groupe de recherche sur les maladies infectieuses du porc (GREMIP), Faculté de médecine vétérinaire, Université de Montréal, Saint-Hyacinthe, QC, \\ Canada \\ d Département des sciences animales, Faculté des sciences de l'agriculture et de l'alimentation, Université Laval, Québec, Canada \\ e Département de biomédecine vétérinaire, Faculté de médecine vétérinaire, Université de Montréal, Saint-Hyacinthe, QC, Canada
}

\section{A R T I C L E I N F O}

\section{Article history:}

Received 27 October 2014

Accepted 10 February 2015

Available online 17 February 2015

\section{Keywords:}

Deoxynivalenol

Immune response

Oxidative stress

Intestine

Pigs

\begin{abstract}
A B S T R A C T
This study was performed to characterize the influence of consuming DON naturally contaminated feeds on pig's intestinal immune defenses, antibody response and cellular immunity. Sixteen 4-week-old piglets were randomly allocated to two dietary treatments: control diet or diet contaminated with $3.5 \mathrm{mg}$ DON $/ \mathrm{kg}$. At days 7 and 21, animals were immunized with ovalbumin (OVA). On day 42, intestinal samples were collected for measurement of gene expression involved in immune response, oxidative status and barrier function. Primary IgG antibody response to OVA was increased in pigs fed DON diet compared to control animals. In the ileum of pigs fed DON diet, claudin, occludin, and vimentin genes involved in integrity and barrier function were down-regulated compared to controls. Results also revealed that expression of two chemokines (IL-8, CXCL10), interferon- $\gamma$, and major antioxidant glutathione peroxidase 2 (GPX-2) were up-regulated whereas expression of genes encoding enzymatic antioxidants including GPX-3, GPX-4 and superoxide dismutase 3 (SOD-3) were down-regulated in pigs fed DON-contaminated diet. These results strongly suggest that ingestion of DON naturally contaminated feed impaired intestinal barrier and immunological functions by modulating expression of genes coding for proteins involved in tight junctions, tissue remodelling, inflammatory reaction, oxidative stress reaction and immune response.

Crown Copyright $\odot 2015$ Published by Elsevier Ltd. This is an open access article under the CC BY license
\end{abstract}

\section{Introduction}

Deoxynivalenol (DON), also known as vomitoxin, is a type B trichothecenes mainly produced by Fusarium fungi. DON is found in wheat and corn (Calvo, 2005) and is among the most commonly encountered mycotoxins throughout the world (Pestka and Smolinski, 2005). American Council for Agricultural Science and Technology (CAST) (CAST, 2003) estimated that mycotoxins affect 25\% of the world's cereal production, including many basic foodstuffs and animal feed. Because it can affect animal productivity, human health and international trade, DON is still a major problem for the food industry. For instance, chronic exposure to low doses of DON can lead to anorexia, and it can reduce weight gain and provoke immunotoxicity, whereas acute exposure to high dose can cause diarrhea, vomiting, leucocytosis, circulatory shock and can ultimately

\footnotetext{
* Corresponding author. Dairy and Swine Research and Development Centre, Agriculture and Agri-Food Canada, 2000 College Street, Sherbrooke, Québec, Canada J1M 0C8. Tel.: +1 819780 7220; fax: +1-819-654-5507.

E-mail address: Martin.Lessard@agr.gc.ca (M. Lessard).
}

lead to death (Pestka and Smolinski, 2005). Animals present different levels of sensitivity to DON and swine are the most affected among farm animals (Prelusky et al., 1994).

Over the years, several studies in pigs have reported intoxication cases by grains infected with Fusarium fungi (Abramson et al., 1997; Moore et al., 1985; Vesonder et al., 1978). Adverse effects in pigs differ depending on ingested concentrations of DON; however, concentration as low as $1.3 \mathrm{mg} / \mathrm{kg}$ has been reported to reduce feed intake and growth performance (Étienne, 2007; Grosjean et al., 2003). Consumption of DON has been shown to affect the systemic immune response of pigs, especially in growing piglets (Accensi et al., 2006; Grosjean et al., 2007). For instance, ingestion of DON has been shown to increase total IgA titer in serum (Accensi et al., 2006; Grosjean et al., 2007) and to disrupt functions of dendritic cells in piglets (Bimczok et al., 2007). Contamination by DON also influences specific immune response to ovalbumin (OVA) vaccination by inducing an increase in IgA and IgG levels directed against OVA (Pinton et al., 2006).

The effects of DON on intestinal natural and immune defenses, oxidative status and barrier function have not been extensively studied. In a recent study, Bracarense et al. (2012) reported that 
ingestion of DON contaminated diet ( $3 \mathrm{mg} / \mathrm{kg}$ ) has adverse effects on intestinal tract of growing pigs. They observed a significant increase of lesional score in jejunum and ileum and decrease in villous height and the number of goblet cells and lymphocytes. They also observed that DON increases mRNA expression of different cytokines involved in the inflammatory response in jejunum and ileum, revealing the presence of active inflammation in the intestine. Using the intestinal porcine epithelial cell line IPEC-1, the same laboratory also reported that DON alters the intestinal function of barrier and inhibits the expression of claudin- 4 protein, which is one important component of tight junction (Pinton et al., 2009).

The influences of DON on intestinal barrier, oxidative status and immune functions are still not well understood. Using the pig as model, the purpose of this study was to characterize the in vivo consequences of consuming DON contaminated feeds on intestinal immune defenses by measuring the modulation of mRNA expression of cytokines, chemokines, enzymes involved in oxidative stress response, tight junction proteins and antimicrobial peptide. The influence of DON on antibody and cellular immune responses after immunization was also studied.

\section{Materials and methods}

\subsection{Experimental diets}

Experimental diets were prepared by F. Ménard Inc. (Ange-Gardien, Qc, Canada) and formulated according to the energy and amino acid requirements for piglets as previously described in the National Swine Nutrition Guide (2010). Wheat used in the experimental diets was naturally contaminated with DON. Dietary contents of DON were analyzed in the final diets using ELISA Kit VERATOX for DON 5/5 (Neogen corporation, Lansing, MI, USA). Two diets were then prepared and adjusted at 0 and $3.5 \mathrm{mg} \mathrm{DON} / \mathrm{kg}$ (Table 1$)$.

\subsection{Animals and treatments}

In vivo experiment was conducted at the Faculté de médecine vétérinaire (FMV), Université de Montréal. Animal care procedures followed the guidelines of the Canadian Council on Animal Care (2009) and the protocol was approved by the Institutional Animal Care Committee. Sixteen commercial Landrace-Yorkshire crossbred piglets were purchased locally (F. Ménard Inc., Ange-Gardien, Qc, Canada) at 4 weeks of age. After one week of acclimation, with a commercial ration, piglets were randomly divided into two experimental groups of 8 animals based on DON content of served diets ( 0 and $3.5 \mathrm{mg}$ of DON/ $\mathrm{kg}$ ). Pigs were fed with experimental diet for 42 days and had ad libitum access to feed and water throughout the whole feeding period. They were weighed weekly for growth performance.

\subsection{Immunization procedure and antibody response to OVA}

Ovalbumin (A5378) and incomplete Freund adjuvant (F5506) were purchased from Sigma-Aldrich Canada (Oakville, ON, Canada). Prior to the immunization, OVA was diluted in PBS and mixed half/half with Freund's incomplete adjuvant (FIA) to

\section{Table 1}

Composition of different experimental diets. ${ }^{a}$

\begin{tabular}{lcc}
\hline $\begin{array}{l}\text { Ingredient } \\
\text { g/kg diet }\end{array}$ & $\begin{array}{l}\text { Control diet } \\
(0 \mathrm{mg} / \mathrm{kg} \mathrm{DON})\end{array}$ & $\begin{array}{l}\text { DON diet } \\
(3.5 \mathrm{mg} / \mathrm{kg} \mathrm{DON})\end{array}$ \\
\hline Wheat $(0 \mathrm{mg} / \mathrm{kg} \mathrm{DON})$ & 713.35 & 389 \\
Wheat $(9 \mathrm{mg} / \mathrm{kg} \mathrm{DON})$ & 0 & 324.5 \\
Soybean meal & 100 & 100 \\
Whey & 75 & 75 \\
Fat & 15 & 15 \\
Phosphate dical.-21\% & 12 & 12 \\
Limestone & 12 & 12 \\
Salt & 3 & 3 \\
Threonine & 3 & 3 \\
Methionine & 1.65 & 1.65 \\
Se mg/kg & 0.4 & 0.4 \\
Vitamin E 10\% & 0.25 & 0.25 \\
Cu chloride 58\% & 0.15 & 0.15 \\
\hline
\end{tabular}

a All diets were formulated to reach the following requirement: metabolizable energy $3200 \mathrm{kcal} / \mathrm{kg}$, protein $19 \%$, fat $3 \%$, fiber $2.5 \%$, moisture $10 \%$, Ca $0.8 \%, \mathrm{Mg}$ $509 \mathrm{mg} / \mathrm{kg}$, total P 0.7\%, K 0.7\%, Na 0.2\%, Se $0.6 \mathrm{mg} / \mathrm{kg}$, Cu $120.4 \mathrm{mg} / \mathrm{kg}$, Zn $250 \mathrm{mg} / \mathrm{kg}$, vitamin A $18.4 \mathrm{KIU} / \mathrm{kg}$, vitamin D $2.5 \mathrm{KIU} / \mathrm{kg}$, vitamin E $106.7 \mathrm{mg} / \mathrm{kg}$, biotin, $0.3 \mathrm{mg} / \mathrm{kg}$. obtain a final solution at $1 \mathrm{mg} / \mathrm{ml}$ of OVA. Piglets were intramuscularly injected at days 7 and 21 of the feeding period with $1 \mathrm{ml}$ OVA:FIA inoculum. Blood samples were taken before the first immunization and then weekly at 14, 21, 28 and 35 days of the feeding period.

\subsection{Isolation of peripheral blood mononuclear cells (PBMC)}

Blood samples $(10 \mathrm{ml})$ were drawn from all piglets at days $0,7,14,21,28$ and 35 of feeding by jugular venepuncture in heparinized collection tubes (BDCanada, Mississauga, ON, Canada). Plasma samples were obtained following centrifugation of $5 \mathrm{ml}$ of heparinized blood at $2000 \mathrm{~g}$ at room temperature. Plasma samples were kept frozen at $-20^{\circ} \mathrm{C}$ until assayed. Peripheral blood mononuclear cells (PBMC) were separated from 1:1 PBS diluted heparinized blood samples ( $5 \mathrm{ml}$ ) using lymphocyte separation media (Wisent Inc., Saint-Bruno, QC, Canada). Diluted samples were layered on lymphocyte separation media and centrifuged at $400 \mathrm{~g}$ for $15 \mathrm{~min}$. Buffy coat were recovered and washed twice with $30 \mathrm{ml}$ of PBS. After the last wash, cells were resuspended in RPMI (Life Technologies (Burlington, ON, Canada) supplemented with $10 \mathrm{mM}$ HEPES, $2 \mathrm{mM}$ L-glutamine, $50 \mu \mathrm{M}$ 2-mercaptoethanol, $1 \mathrm{mM}$ sodium pyruvate, $5 \mathrm{U} / \mathrm{ml}$ penicillin, $5 \mu \mathrm{g} / \mathrm{ml}$ streptomycin, $2.5 \mu \mathrm{g} / \mathrm{ml}$ fungizone and $10 \%$ fetal bovine serum (Wisent Inc., St-Bruno, QC, Canada). Cell concentration was adjusted to a final concentration of $2 \times 10^{5}$ cells by wells.

\subsection{Ovalbumin-specific antibody titration by ELISA}

Ovalbumin at $0.5 \mu \mathrm{g} / \mathrm{ml}$ were diluted in PBS ( $\mathrm{pH} 7.4$ ) and $100 \mu \mathrm{l} /$ well of diluted antigens were coated overnight at $4{ }^{\circ} \mathrm{C}$ in Costar ${ }^{\mathrm{TM}}$ 96-Well EIA/RIA plates (Fisher Scientific, Ottawa, On, Canada). Well coating surface was then blocked with PBS/0.1\% Tween-20/2\% BSA ( $150 \mu \mathrm{l} /$ well) for $1 \mathrm{~h}$ at $37^{\circ} \mathrm{C}$. After washing three times with $\mathrm{PBS} / 0.1 \%$ Tween-20, sera were added in 2-fold serial dilutions starting from 1:50. The plates were incubated for $90 \mathrm{~min}$ at $37^{\circ} \mathrm{C}$, washed four times and then incubated with $100 \mu \mathrm{l}$ of horseradish peroxidase (HRP)-conjugated rabbit anti-porcine IgG (Life Technologies Inc. Burlington, ON, Canada) or HRP-conjugated goat anti-porcine IgA (Abcam Inc., Toronto, ON, Canada) at a dilution of $1 / 2000$ and $1 / 10,000$ respectively in PBS/0.1\% Tween-20/2\% BSA for $1 \mathrm{~h}$ at $37^{\circ} \mathrm{C}$. After four washes, the presence of IgG and IgA was detected with $100 \mu$ of TMB single solution (Life Technologies Inc. Burlington, ON, Canada) according to the manufacturer's instructions. The reaction was stopped by adding $100 \mu \mathrm{l}$ of $0.18 \mathrm{M} \mathrm{H}_{2} \mathrm{SO}_{4}$. The OD was read at $450 \mathrm{~nm}$ using a Synergy ${ }^{\mathrm{TM}}$ HT multi-detection microplate reader (Biotek, Winooski, VT, USA). Results were expressed as an antibody endpoint titer, determined when the OD value was 2 -fold greater than the background value obtained with the same dilution of serum from pre-immune pig.

\subsection{Lymphoproliferation assay}

Cells were reactivated with either culture medium alone or with concanavalin A (Con A, Sigma-Aldrich, Oakville, ON, Canada) at $10 \mu \mathrm{g} / \mathrm{ml}$ or with OVA at $100 \mu \mathrm{g} / \mathrm{ml}$ and were cultured for 3 days at $37{ }^{\circ} \mathrm{C}, 5 \% \mathrm{CO}_{2}$. Cells were incubated with 5-Bromo2 '-deoxy-uridine (BrdU) for the last 16 hours of incubation following manufacturer instructions. BrdU incorporation was revealed with BrdU cell proliferation assay kit (EMD Inc. Mississauga, ON, Canada) as specified by manufacturer instructions. The absorbance of the samples was measured using the microplate reader at $450 \mathrm{~nm}$. Data were expressed as stimulation index (SI) which is calculated by dividing the stimulated sample by the non-stimulated control sample.

\subsection{Measurement of plasma C-reactive protein by ELISA}

Plasma samples kept frozen were used for cytokine measure. There were collected at 0,14 and 28 days of feeding. ELISAs were performed in accordance with manufacturer recommendations without modification (CRP: DY2648, DuoSet $₫$, R\&D System, MN, USA).

\subsection{Quantification of intestinal cytokines, oxidative stress enzymes, tight junction proteins and antimicrobial peptide by real-time PCR}

Pigs were euthanized at the end of the feeding period on day 42 . They were anesthetized by intramuscular injections of $2 \mathrm{mg} / \mathrm{kg}$ of azaperon (Stresnil, Janssen Pharmaceutica, Beerse, Belgium), $2 \mathrm{mg} / \mathrm{kg}$ xylazine (Xylamax, Bimeda-MTC Animal Health, Cambridge, ON, Canada) and $20 \mathrm{mg} / \mathrm{kg}$ ketamine (Vetalar, Bioniche Animal Health, Belleville, ON, Canada) prior to being sacrificed by intravenous overdose of sodium pentobarbital (Eutanyl Forte 540, Bimeda-MTC Animal Health, Cambridge, ON, Canada). Within 15 minutes after death, intestinal mucosa samples from jejunum and ileum were collected for RNA extraction. Jejunum slices were taken at $75 \mathrm{~cm}$ caudally from the stomach while ileum slices were taken at $25 \mathrm{~cm}$ cranially from the cecum. Intestinal mucosa slices were immediately frozen in liquid nitrogen and stored at $-80^{\circ} \mathrm{C}$ until assays were performed. Briefly, ileum and jejunum slices were homogenized in RLT Plus (Qiagen, Toronto, Canada)/ $\beta$-mercaptoethanol/DX reagent (Qiagen) buffer using a Polytron homogenizer (Kinematica, New York, USA). Total RNA was extracted with RNeasy Plus mini kit (Qiagen) following the manufacturer's recommendations and was resuspended in $50 \mu \mathrm{L}$. Total RNA was quantified using a NanoDrop spectrometer (NanoDrop Technologies, Inc., Wilmington, DE, USA) at 
Table 2

List of genes and sequences of the primers used for real-time PCR.

\begin{tabular}{|c|c|c|c|c|}
\hline Gene family & $\begin{array}{l}\text { mRNA } \\
\text { target }^{\mathrm{a}, \mathrm{b}}\end{array}$ & Accession number & Primers $\left(5^{\prime} \rightarrow 3^{\prime}\right)^{c}$ & Final conc. (nM) \\
\hline \multirow[t]{6}{*}{ Reference genes } & \multirow{2}{*}{$H 3 F 3 A^{I}$} & \multirow[t]{2}{*}{ NM_213930.1 } & F: CGTCTGGTGCGGGAAATT & 300 \\
\hline & & & R: TCAAAAAGGCCAACCAGATAGG & 150 \\
\hline & \multirow[t]{2}{*}{ RPL32I } & \multirow[t]{2}{*}{ NM_001001636.1 } & F: TGCTCTCAGACCCCTTGTGAAG & 150 \\
\hline & & & R: TTTCCGCCAGTTCCGCTTA & 150 \\
\hline & \multirow[t]{2}{*}{ RPS $18^{I}$} & \multirow[t]{2}{*}{ NM_213940.1 } & F: CATGTGGTGTTGAGGAAAGCA & 300 \\
\hline & & & R: TTGGCGAGGATTCTGCATAAT & 150 \\
\hline \multirow[t]{16}{*}{ Genes modulated by inflammatory reaction } & \multirow{2}{*}{$I F N G^{A}$} & \multirow[t]{2}{*}{ NM_213948.1 } & F: AGGTTCCTAAATGGTAGCTCTGGG & 300 \\
\hline & & & R: AGTTCACTGATGGCTTTGCGCT & 300 \\
\hline & \multirow[t]{2}{*}{$I L 1 B^{I}$} & \multirow[t]{2}{*}{ NM_001005149.1 } & F: GTGGACTGCAAACTCCAGGACAAA & 300 \\
\hline & & & R: GCTCATGCAGAACACCACTTCTCT & 900 \\
\hline & \multirow[t]{2}{*}{$I L 4^{I}$} & \multirow[t]{2}{*}{ NM_214123.1 } & F: GGTCTGCTTACTGGCATGTACC & 900 \\
\hline & & & R: CTCCATGCACGAGTTCTTTCTC & 300 \\
\hline & \multirow[t]{2}{*}{ IL6 $6^{A}$} & \multirow[t]{2}{*}{ NM_214399.1 } & F: GGAAATGTCGAGGCTGTGCAGATT & 300 \\
\hline & & & R: GGTGGTGGCTTTGTCTGGATTCTT & 300 \\
\hline & \multirow[t]{2}{*}{ IL $10^{A}$} & \multirow[t]{2}{*}{ NM_214041.1 } & F: GATATCAAGGAGCACGTGAACTC & 300 \\
\hline & & & R: GAGCTTGCTAAAGGCACTCTTC & 300 \\
\hline & IL12B ${ }^{A}$ & NM_214013.1 & F: GCCAAGGTTACATGCCACAA & 300 \\
\hline & & & R:TAGAACCTAATTGCAGGACACAGATG & 900 \\
\hline & $T N F^{A}$ & NM_214022.1 & F: CACTGACCACCACCAAGAATTGGA & 300 \\
\hline & & & R: CATTCCAGATGTCCCAGGTTGCAT & 300 \\
\hline & PTGS2I & NM_214321.1 & F: AAGCGAGGACCAGCTTTCACCAAA & 300 \\
\hline & & & R: GCGCAGTTTATGCTGTCTCTCCAA & 300 \\
\hline Genes involved in epithelial defense & $D E F B 1^{I}$ & NM_213838.1 & F: ACCGCCTCCTCCTTGTATTC & 300 \\
\hline & & & R: GGTGCCGATCTGTTTCATCT & 300 \\
\hline & $P D B-2^{A}$ & NM_214442.1 & F:CCGACCACTACATATGTGCCAAGA & 300 \\
\hline & & & R: TGCCACTGTAACAGGTCCCTTCAA & 300 \\
\hline & $C L D N 3 / 4^{l}$ & NM_001160075.1 NM_001161637.1 & F: CGTCACGGCCTTCATCGGCA & 300 \\
\hline & & & R: TCGTACACTTTGCACTGCATCTGG & 300 \\
\hline & $O C L N^{I}$ & NM_001163647.1 & F: CGACGAGCTGGAGGAAGACT & 300 \\
\hline & & & R: TGCAGGCCACTGTCAAAATTT & 150 \\
\hline & Vimentin-like $e^{A}$ & XM_003130721 & F: GGAGTCAAATGAGTACCGGAGACA & 300 \\
\hline & (LOC100522394) & & R: GTTAGCAGCTTCCACGGCAAAGTT & 900 \\
\hline Genes involved in apoptosis & $B C L 2^{I}$ & XM_003121700.2 & F: AGGATTGTGGCCTTCTTTGAGTT & 300 \\
\hline & & & R: CGGTTCAGGTACTCAGTCATCCA & 900 \\
\hline & $B C L 2 L 1^{I}$ & NM_214285.1 & F: GGTACCGGAGGGCATTCAG & 150 \\
\hline & & & R: ACAATGCGACCCCAGTTCAC & 300 \\
\hline Chemokines & $I L 8^{A}$ & NM_213867.1 & F: AGAACTGAGAAGCAACAACAACAG & 300 \\
\hline & & & R: CACAGGAATGAGGCATAGATGTAG & 300 \\
\hline & CXCL10 $0^{I}$ & NM_001008691.1 & F: ACTGAAAGCAATTAGCAAAGAAAGGT & 300 \\
\hline & & & R: AGAGAGATGATGGCAGAGGTAGATTC & 300 \\
\hline & $C C L 4^{I}$ & NM_213779.1 & F: CATACACCGTGCGGAAGCTT & 300 \\
\hline & & & R: TGCCCTTTTTGGTCTGGAATAC & 300 \\
\hline & $C C L 2^{A}$ & NM_214214.1 & F: GGCTGATGAGCTACAGAAGAGTCA & 300 \\
\hline & & & R: CTTGGGTTCTGCACAGATCTCCTT & 300 \\
\hline Genes involved in oxidative stress & $G P X 2^{I}$ & NM_001115136.1 & F: TGCAACCAATTTGGACATCAG & 150 \\
\hline & & & R: TTCACGTCACACTTCTGGATAAGG & 300 \\
\hline & $G P X 3^{I}$ & NM_001115155.1 & F: AAACAGGAACCGGGAGACAA & 300 \\
\hline & & & R: AGGACAGGCGTTCTTCAGGAA & 150 \\
\hline & $G P X 4^{I}$ & NM_214407.1 & F: TCCATGCACGAATTCTCAGCCAAG & 300 \\
\hline & & & R: TCATTGAGAGGCCACATTGGTGAC & 300 \\
\hline & SOD2 $2^{I}$ & NM_214127.2 & F: TCTGGACAAATCTGAGCCCTAAC & 300 \\
\hline & & & R: CGGATACAGCGGTCAACTTCTC & 900 \\
\hline & NOS2 $2^{I}$ & NM_001143690.1 & F: CCACGCCCCCAACTCA & 900 \\
\hline & & & R: TGGTGAACTTCCACTTGTTGTAGTC & 300 \\
\hline & SOD ${ }^{I}($ LOC780439) & NM_001078688.1 & F: ATGCTGACGCTGCTCTGTGCTTA & 900 \\
\hline & & & R: TCCTGCCAGATCTCCGTCACTTT & 300 \\
\hline
\end{tabular}

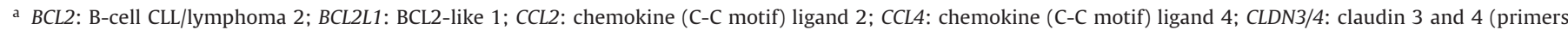

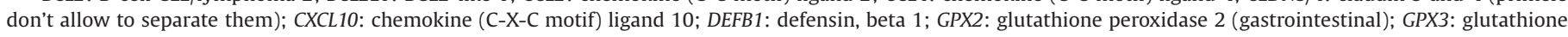

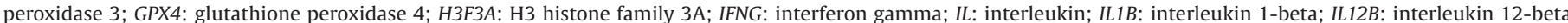

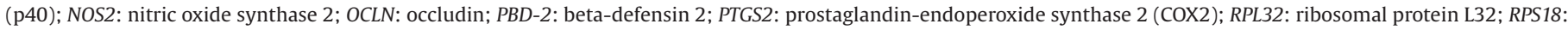

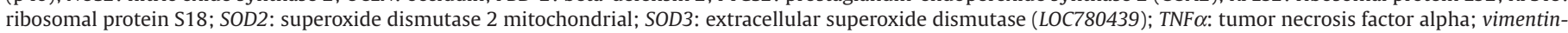
like: vimentin (LOC100522394)

b I: Integrated DNA Technologies, A: Applied Biosystems.

c $\mathrm{F}$ : forward primer, R: reverse primer.

a wavelength of $260 \mathrm{~nm}$. Purity was assessed by determining the ratio of absorbance at 260 and $280 \mathrm{~nm}$ (A260/A280). All samples had a ratio between 1.9 and 2.1. The ratio of absorbance at 260 and $230 \mathrm{~nm}$ (A260/A230) was also measured and all samples had a ratio between 1.7 and 2.1. A $1 \mu \mathrm{g}$ aliquot of total RNA was reversetranscribed with Superscript II reverse transcriptase (Invitrogen) using oligo (dT)1218 primer (Invitrogen) in a final volume of $20 \mu \mathrm{L}$, according to the supplier's instructions. The cDNA samples were diluted 1:15 in nuclease-free water and aliquots were stored at $-20^{\circ} \mathrm{C}$ prior to real-time PCR analysis.
Real-time PCR was performed using Step One Plus Real-Time PCR System (Applied Biosystems, Foster City, USA) to evaluate the mRNA modulation of the genes listed in Table 2. The PCR mixture was composed of the following: $5 \mu$ L Power SYBR Green Master Mix (Applied Biosystems), $2 \mu$ l of each gene specific primer set (IDT, Coralville, USA or Applied Biosystems) at the indicated concentrations (Table 1 ), $3 \mu$ L of diluted 1:15 cDNA. Primers were selected using the following criteria, when possible: (1) both forward and reverse primers encompass two consecutive exons; and (2) no more than two guanines or cytosines within the last five nucleotides in the 3' termini. 
The PCR cycling conditions were $10 \mathrm{~min}$ at $95^{\circ} \mathrm{C}$, followed by 40 cycles of $5 \mathrm{sec}$ at $95^{\circ} \mathrm{C}$ and $30 \mathrm{sec}$ at $60{ }^{\circ} \mathrm{C}$, and finally a dissociation curve was done. The mRNA expression levels were determined using a relative standard curve established by serial dilutions of a cDNA pool composed of all piglets included in the study. In order to confirm the specificity of the measured amplicons (i.e. the presence of only one amplicon), the melting curve was systematically analyzed for all samples. Each run included a no-template control to detect DNA contamination of the reagents and each sample was tested in triplicate. All cDNA samples were analyzed for the expression of three different reference genes: $\mathrm{H} 3$ histone family $3 \mathrm{~A}(\mathrm{H} 3 \mathrm{~F} 3 \mathrm{~A})$, ribosomal protein L32 (RPL32) and ribosomal protein S18 (RPS18). The combination of these three reference genes was reported to be the most suitable for normalization in multiple tissues in pigs (Zhang et al., 2012). Statistical analyses were performed and results indicated that these reference genes were adequate in our experiment as their expression was not modulated by the tissues or treatments administered to the pigs.

\subsection{Statistical analysis}

For growth, antibody and T-cell responses, pair-wise mean comparisons between control and DON treated animals were made using Student's unpaired ' $t$ ' test. For C-reactive protein and gene expression, results were analyzed using the MIXED procedure of SAS (SAS Institute Inc, 2009). Data on C-reactive protein were subjected to repeated measures analysis. Data on mRNA abundance were analyzed using the normalized quantities and are presented as relative quantification of mRNA abundance using the comparative $\mathrm{Ct}$ method comparing all treatment combinations to the control diet, used here as reference.

\section{Results}

\subsection{DON effect on growth performance of piglets}

Average daily gain of pigs fed control uncontaminated diet was significantly higher than animals fed diet containing $3.5 \mathrm{mg} \mathrm{DON} / \mathrm{kg}$ $(p=0.02$; Fig. 1$)$. In pigs fed DON diet, average daily gain was $12 \%$ less than in control pigs.

\subsection{DON effect on humoral and cellular immunity of piglet}

Circulating levels of systemic markers of humoral immunity were measured in blood of all pigs involved in the study. Results

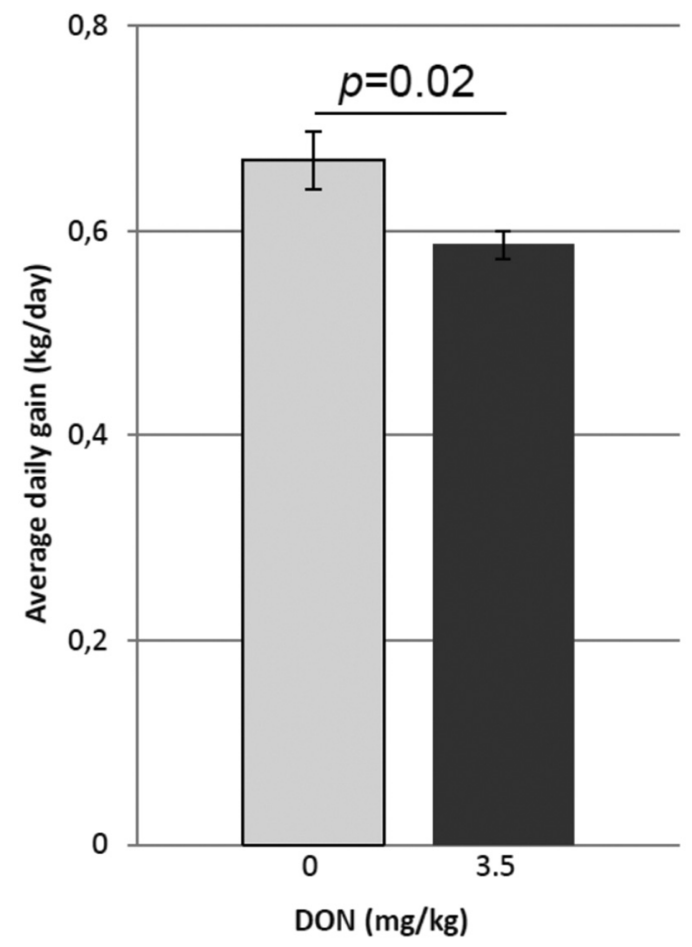

Fig. 1. Influence of DON naturally contaminated diet on piglet's growth. The average daily gain was calculated by dividing the total weight gain during the study by the number of days of the study (42 days). Results are presented as mean $\pm \mathrm{SEM}$. showed that serum concentration of C-reactive protein (CRP) was significantly reduced $(p=0.02)$ in pigs fed DON naturallycontaminated diet for 28 days compared to pigs fed uncontaminated diet (Fig. 2).

Two weeks after the first immunization with OVA (day 21 of feeding), specific primary IgG antibody response was significantly increased $(p=0.05)$ in pigs fed DON-contaminated diet compared to animals fed uncontaminated diet (Fig. 3A). At that time point, OVAspecific IgG titer was approximately 3.5 times higher in pigs fed DON diet compared to control animals. Seven days after the boost injection at day 28 of feeding, OVA-specific IgG antibody response was similar in both groups.

On the other hand, measurement of IgA antibody's specific response to OVA indicated that IgA titers were similar between treatments up to 28 days post-immunization (Fig. 3B). On day 28 post-immunization (day 35 of feeding), IgA titer tended to be lower in pigs fed DON diet than in control pigs $(p=0.07)$.

The proliferative capacity of PBMC stimulated with Con A was similar between piglets fed either DON contaminated or control diet at all times of the feeding period (Fig. 4A). However, using OVA as recall antigen to activate PBMC specific cellular response, lymphocyte proliferative response showed a tendency to be higher $(p=0.06)$ in piglets fed DON contaminated diets 7 days post-immunization, day 14 of feeding (Fig. 4B).

\subsection{Influence of DON on intestinal immune function and epithelial barrier integrity}

In order to determine the global effect of DON on intestine defenses of pigs, mRNA expression of many genes playing key roles in the integrity and permeability of the epithelial barrier, oxidative status and inflammatory response was quantified. Results from RT-PCR analysis showed that in pigs fed DON naturally contaminated diet for 42 days, the intestinal expression of cytokine and

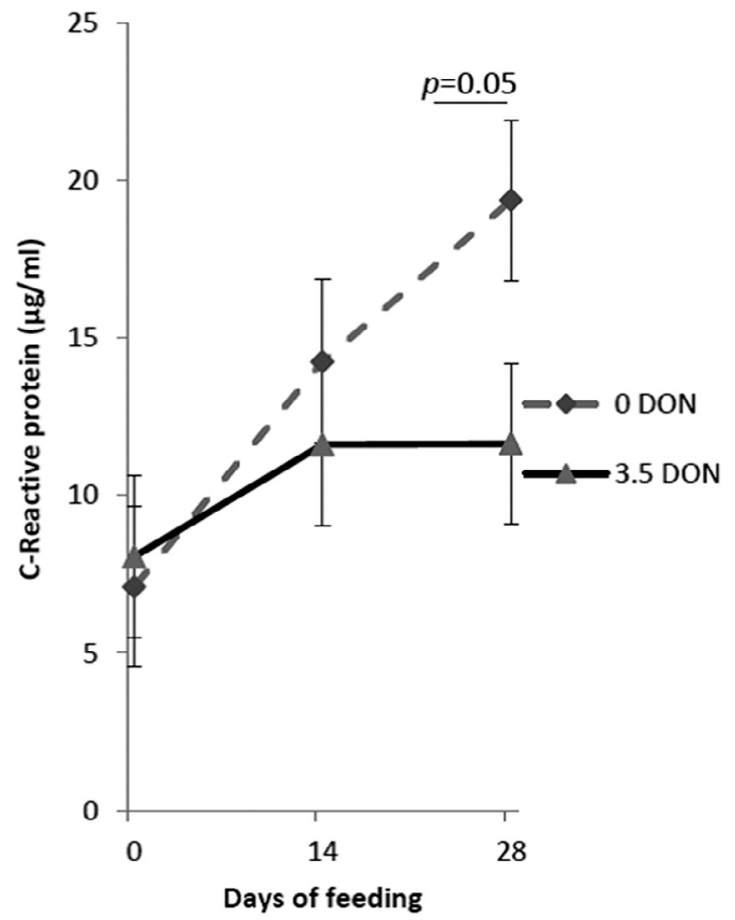

Fig. 2. Blood C-reactive protein (CRP) concentration in piglets exposed to DON naturally contaminated diet. Concentration $(\mu \mathrm{g} / \mathrm{ml})$ of CRP in blood sample of piglets consuming 0 or $3.5 \mathrm{mg} \mathrm{DON} / \mathrm{kg}$ measured at days 0,14 and 28. Results are presented as mean \pm SEM. 

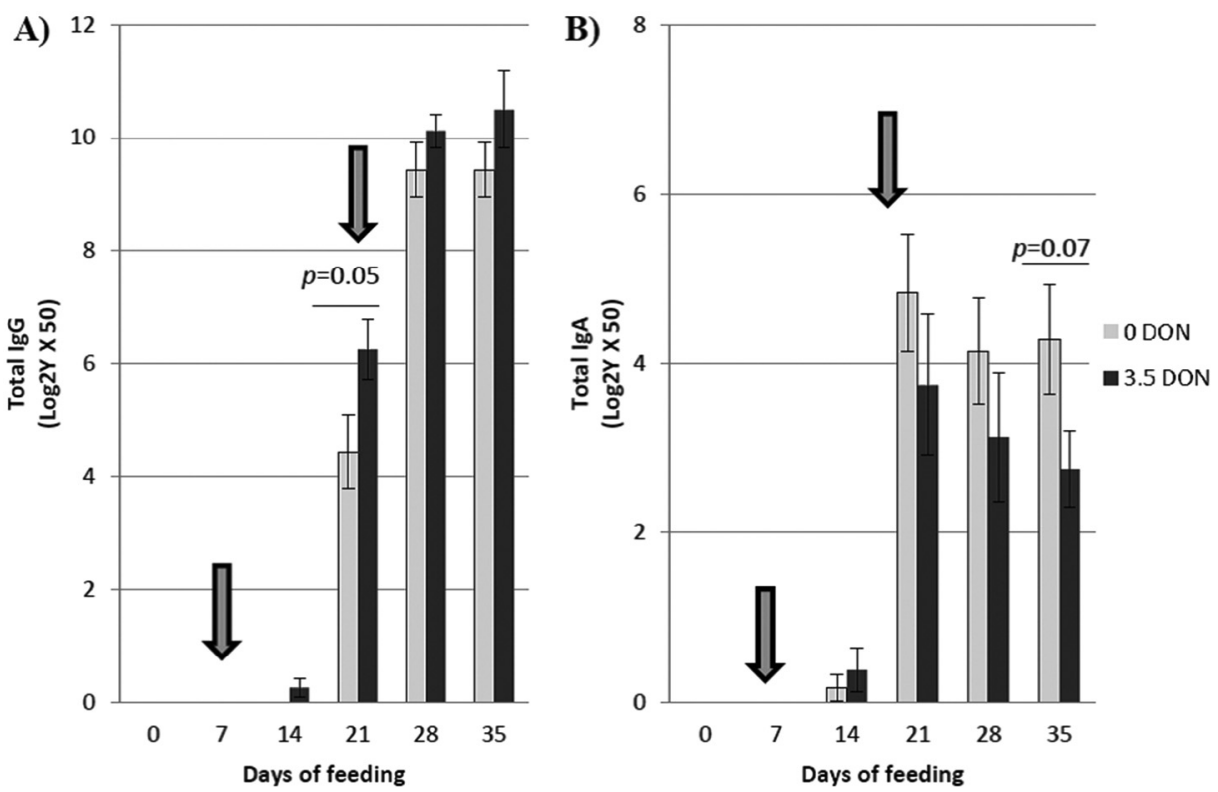

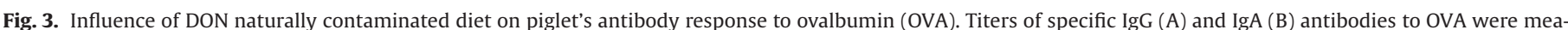

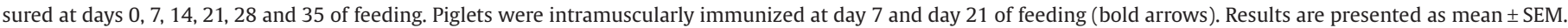

chemokine genes was modulated (Fig. 5). Among genes studied that are known to be modulated by inflammatory reaction, only the expression of IFNG was significantly up-regulated by 2.24 fold $(p=0.05)$ in the ileum of pigs fed DON diet while IL6 gene expression tended to be decreased by 1.18 fold ( $p=0.08$ ). In jejunum, the mRNA expression of IL4 was found to be 1.61 fold higher in pigs fed DON diet than controls $(p=0.04)$. After 42 days of feeding, mRNA expression levels of IL1 $\beta$, IL10, IL12 $\beta$, PTGS2 and TNF- $\alpha$ were not influenced by DON in intestinal tissues (results not shown).

Intestinal expression of chemokine genes involved in recruiting immunocompetent cells at inflammatory sites was also modulated by the presence of DON in the diet (Fig. 5). Results indicated that mRNA expression of IL8 and CXCL10 in the ileum of pigs fed DON diet was increased by 1.59 fold $(p=0.05)$ and 2.14 fold $(p=0.01)$ respectively compared to control group. In the jejunum, CXCL10 was the only chemokine that was significantly increased $(p=0.01)$ by DON diet. After 42 days of feeding, intestinal expression of CCL4 and CCL2 was not influenced by dietary treatments.

Genes related to oxidative stress response were also modulated in pigs fed DON diet (Fig. 6). These animals presented a significant 3.65 fold increase of NOS2 expression in jejunum $(p=0.001)$. Such increase was not observed at the ileum level. Furthermore, five antioxidant enzymes were studied in both jejunum and ileum sections. In pigs fed DON diet, mRNA expression of GPX2 in the ileum showed a significant increase of 1.48 fold $(p=0.05)$ whereas GPX3 and GPX4 mRNA expression levels were significantly decreased by
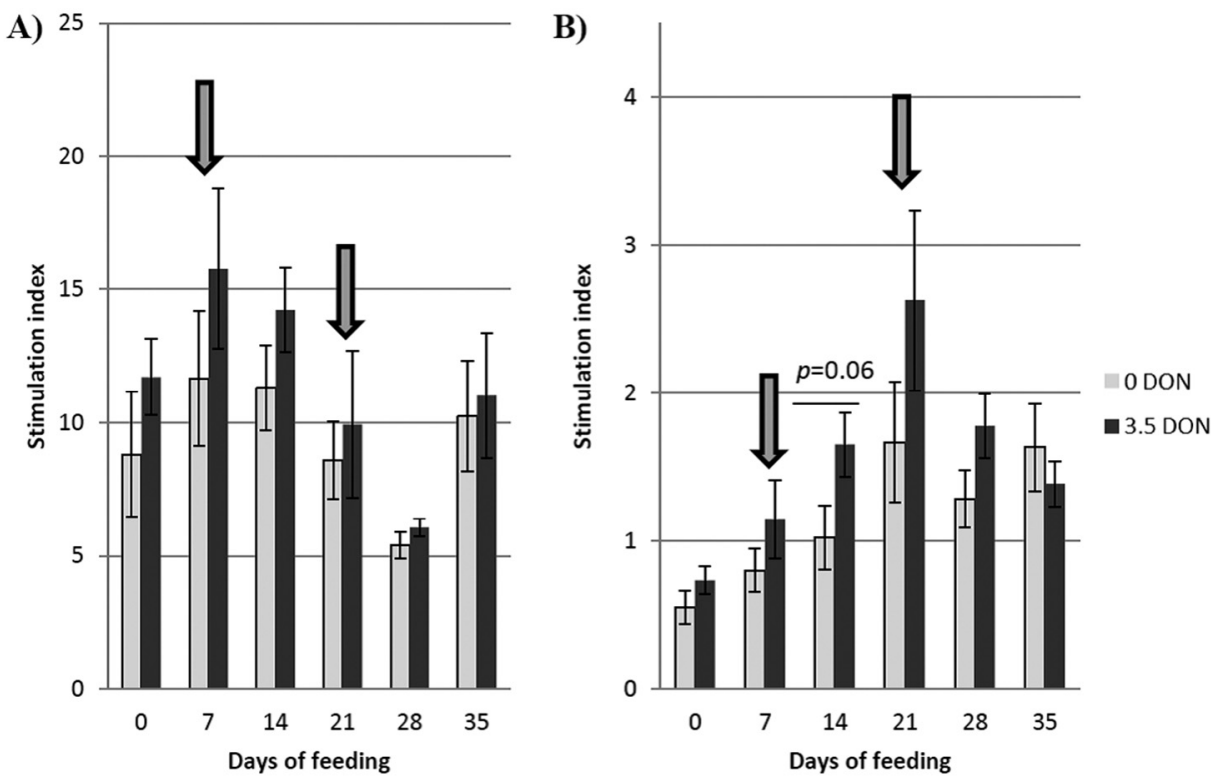

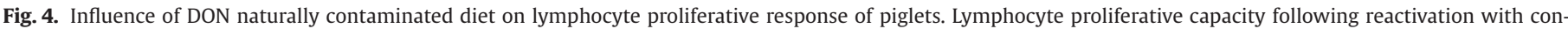

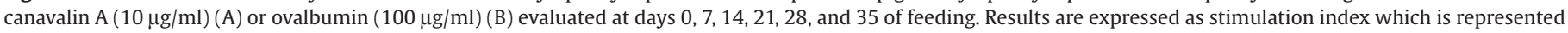
by the ratio of stimulated on non-stimulated cells. Bold arrows indicate first and second immunization. Results are presented as mean \pm SEM. 
Jejunum

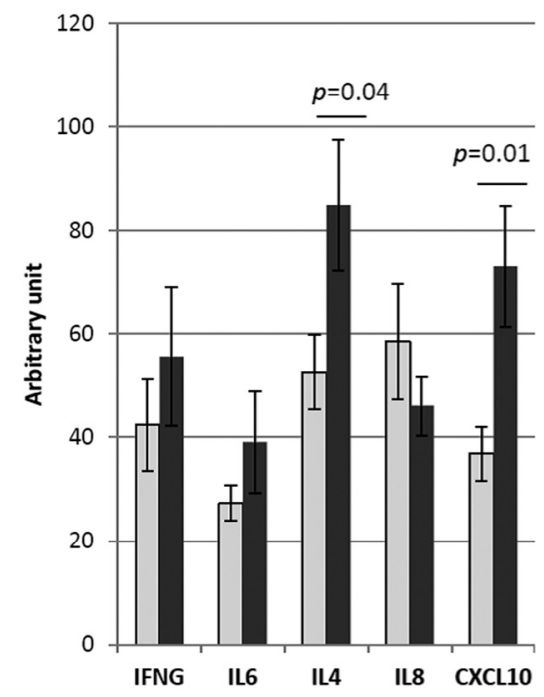

Ileum

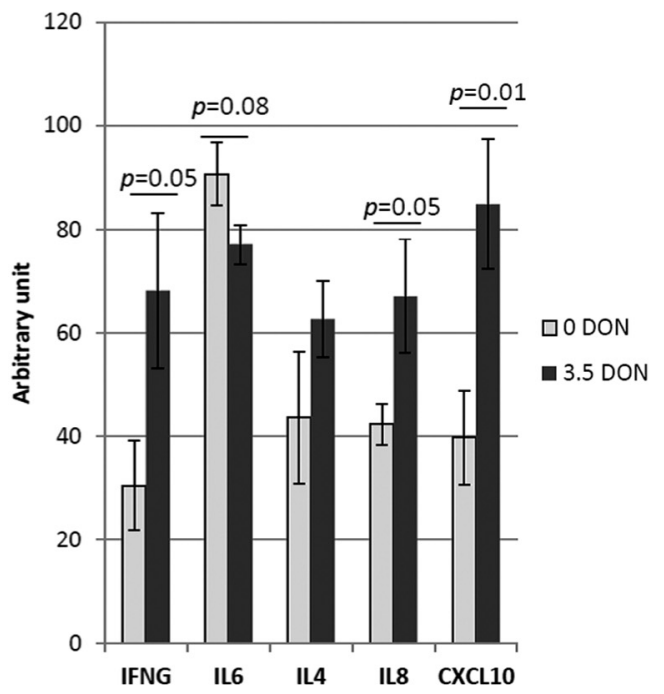

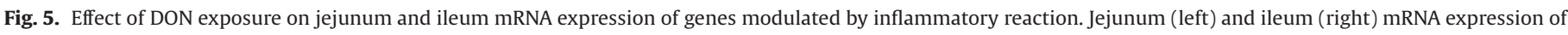

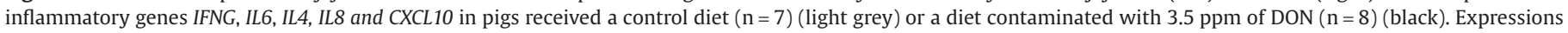
are in arbitrary unit and were corrected with 3 housekeeping genes (RPS18, RPL32 and H3F3A). Results are presented as mean \pm SEM.

Jejunum

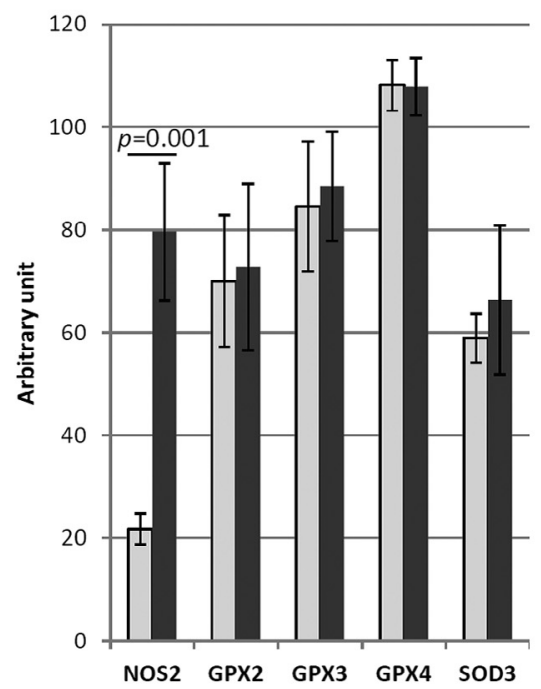

Ileum

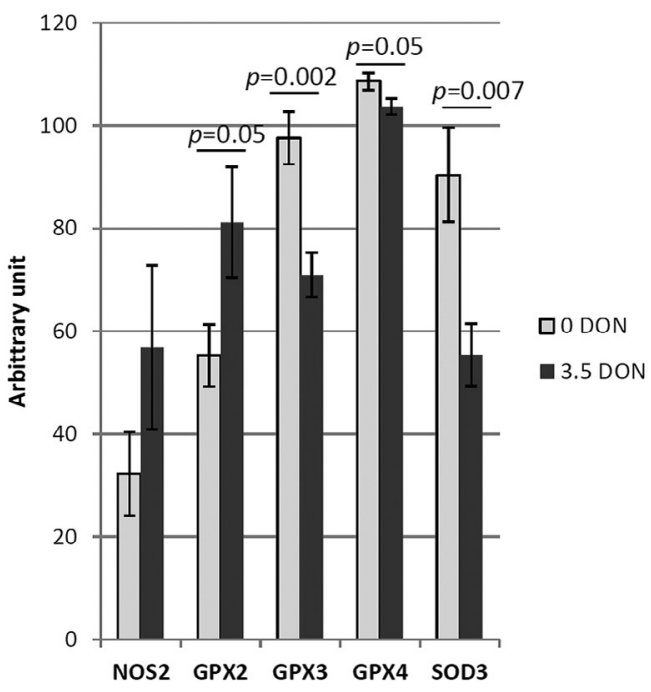

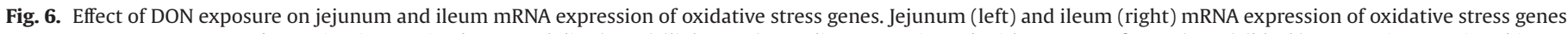

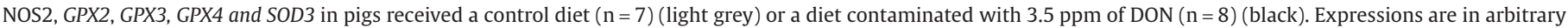
unit and were corrected with 3 housekeeping genes (RPS18, RPL32 and H3F3A). Results are presented as mean \pm SEM.

1.37 fold $(p=0.002)$ and 1.05 fold $(p=0.05)$ respectively compared to control pigs. The ileum mRNA expression of SOD3 was also significantly decreased by 1.63 fold $(p=0.007)$ in ileum in pigs fed DON diet whereas SOD2 expression was not modulated. The mRNA expression of all these antioxidant enzymes was not affected by DON treatment in the jejunum.

The mRNA expression of tight junction proteins, claudins and occludin was significantly influenced in pigs fed DON diet (Fig. 7). mRNA expression of claudin-3 and 4 and occludin were respectively decreased by a fold change of $1.34(p=0.007)$ and $1.30(p=0.03)$ in the ileum of pigs fed DON naturally contaminated diet. The mRNA expression of vimentin-like (encoded by LOC100522394 gene) known to stabilize the cell cytoskeleton structure of myofibroblast present in subepithelial layer was also significantly decreased by 1.31 fold $(p=0.004)$ in ileum of DON fed pigs. Expression of the anti-microbial peptide $\beta$-defensin 1 , encoded by $D E F B 1$ gene, tended to be slightly decreased by DON $(p=0.10)$ in the ileum, but remained unchanged in the jejunum. Intestinal expression $P B D-2$ gene encoding for $\beta$-defensin 2 was not modulated by dietary treatment (results not shown).

Finally, in pigs fed DON diet, a significant 1.27 fold decrease in ileum expression of anti-apoptotic BCL2 was observed $(p=0.04)$ (Fig. 6) while BCL2L1 mRNA expression was unchanged in both jejunum and ileum tissues (results not shown). 
Jejunum

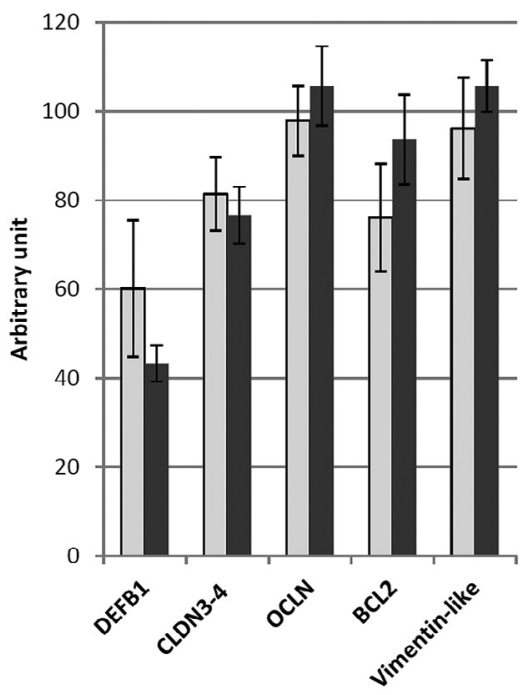

Ileum

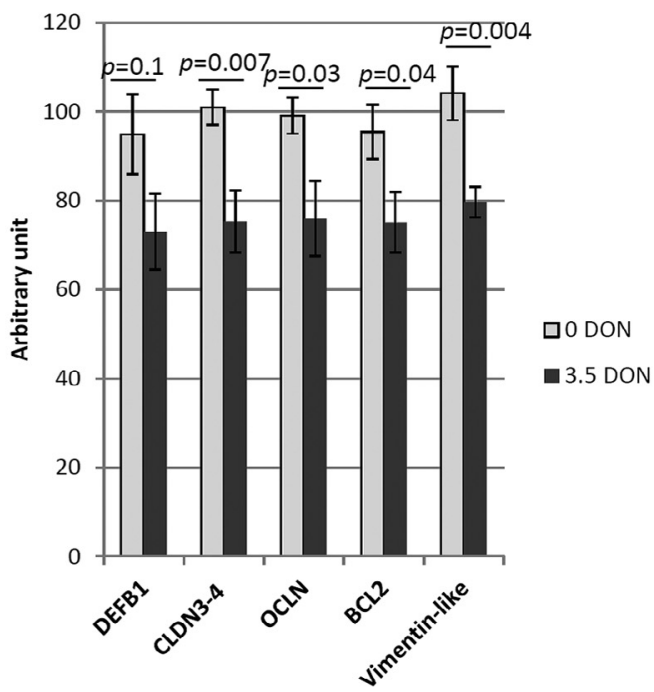

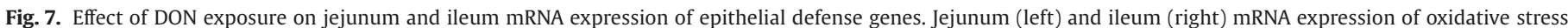

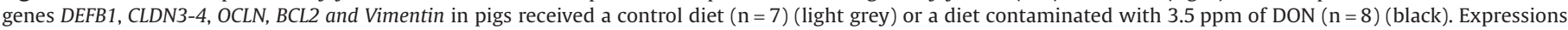
are in arbitrary unit and were corrected with 3 housekeeping genes (RPS18, RPL32 and H3F3A). Results are presented as mean \pm SEM.

\section{Discussion}

Interactions between gastrointestinal tract and dietary components are multifaceted and involve at least intestinal epithelial cells and heterogeneous populations of immune cells playing important roles in innate and adaptive immunity. Therefore, the intestine, as the first barrier, is known to play a major role in protecting the host against different microbial and feed antigens such as DON. There is clear evidence that exposure to DON has detrimental effects on pig's health but the underlying molecular mechanisms still need to be elucidated. In the present study, the influence of ingesting DON naturally contaminated feed on intestinal natural and immune defenses, antibody response and lymphocyte proliferation was investigated in weanling piglets.

As previously reported, ingestion of DON contaminated feed impaired weight gain of weaning pigs (Andretta et al., 2012; Doll et al., 2003; Swamy et al., 2003). It has been also shown that lower growth performance caused by DON contaminated feed resulted mainly from reduced voluntary feed intake (Accensi et al., 2006; Bergsjø et al., 1993; Goyarts and Danicke, 2005; Pestka, 2007; Rotter et al., 1996; Xiao et al., 2013). Therefore, although feed intake was not measured in this study, the effect of DON on average daily gain was probably due to impaired feed intake.

Several studies have also reported that DON has a limited effect on antibody response in pigs (Overnes et al., 1997; Pinton et al., 2008; Rotter et al., 1994). In the present study, results revealed a slight increase in the primary IgG response but, as described in previous studies (Overnes et al., 1997; Pinton et al., 2008; Rotter et al., 1994), no major effect was observed during the secondary immune response induced by the boost injection. With regard to the influence of DON on serum IgA, our results are rather inconsistent with others from previous studies. Indeed, it has been reported that levels of IgA increase after dietary DON exposure reported in pigs (Drochner et al., 2004; Pinton et al., 2008), whereas IgA secretion is impaired in the supernatant of stimulated peripheral blood mononuclear cells incubated with increasing DON concentrations for $72 \mathrm{~h}$ (Goyarts et al., 2006). This contrasts with our results showing that IgA titer tended to be reduced with time post-immunization. However, this observation corroborated those from other studies that also failed to show any significant interactions between DON and IgA serum concentrations (Goyarts et al., 2006; Swamy et al., 2003).

In the present study, we observed that lymphocyte response to Con A was not affected by exposure to DON whereas specific lymphocyte proliferative response to OVA tended to be increased only on day 7 after the first immunization compared to controls. These results are in agreement with those reported by Pinton et al. (2008) indicating that DON contaminated diet has a biphasic effect on specific lymphocyte proliferative response with an increase in the first week after immunization and then a decrease at a later time.

For the first time to our knowledge, decreased concentration of blood CRP, an acute phase protein, was observed with time in pigs consuming $3.5 \mathrm{mg} \mathrm{DON} / \mathrm{kg}$. At the same concentration of DON or even lower, it has been previously reported (Bergsjø et al., 1993; Chen et al., 2008) that DON contaminated feed induces a decrease in serum protein, including albumin, which is also mainly produced by the liver as CRP. These effects of DON on protein synthesis by the liver may be secondary to reduced feed intake but DON itself may also play some role in the inhibition of protein synthesis in the liver (Bergsjø et al., 1993; Chen et al., 2008; Rotter et al., 1996).

In the present study, the most pronounced effects of DON naturally contaminated feed ingested by growing pigs were observed on the expression of several intestinal genes involved in intestinal barrier function, immune response and oxidative stress reactions. Increased ileum expression of IFNG and chemokines IL8 and CXCL10 indicated that DON exposure induced inflammatory response and appeared to activate Th1 response (Asnagli and Murphy, 2001; Szabo et al., 2003). These results are in agreement with previous results indicating that DON exposure up-regulated gene expression of other pro-inflammatory cytokines such as TNF- $\alpha$, IL6 and IL1 $\beta$ in pigs (Bracarense et al., 2012) and in mice (Wu et al., 2014b). The difference between these studies in the expression of inflammatory cytokines could be explained by the kinetic of DON's influence on the immune response. In the present study, we noted an increase in the expression of IFNG and chemokines that are normally up-regulated following the activation of innate immune response by TNF- $\alpha$, IL6 and IL1 $\beta$ (Belardelli and Ferrantini, 2002; Walsh and Mills, 2013). We also reported that IL10 and IL4 
expressions in the ileum were not affected while IL4 and CXCL10 were up-regulated in the jejunum. Therefore, it is likely that proinflammatory cytokines had been also up-regulated by DON prior to the induction of IFNG, IL8 and CXCL10 in the ileum. These results also indicated that the influence of DON on the mRNA expression of cytokines and other molecules are not consistent in the different parts of the intestine. Previous study also stated that immune activation and production of inflammatory cytokines decrease feed intake and growth (Goodband et al., 2014), which is in agreement with the lower weight gain observed following ingestion of DON contaminated feed.

In vitro and in vivo studies have reported that oxidative stress through the induction of inflammatory cytokine production is important for the toxicity of trichothecenes (Pestka, 2007; Wu et al., 2014a). In the present study, a marked increase of NOS2, an inflammatory oxidative enzyme involved in the generation of reactive oxygen and nitrogen species by the neutrophils, was observed in the jejunum of pigs fed DON contaminated diet. In the ileum, NOS2 expression was not significantly up-regulated but the expression of the antioxidant enzymes GPX2, GPX3, GPX4 and SOD3 were found to be modulated. It is interesting to note that GPX2 which encodes for a glutathione peroxidase enzyme known to be mainly expressed in the gastrointestinal system (Chu et al., 1993) was upregulated in the ileum section. GPX2 is a crucial intestinal antioxidant that ranks highest in the hierarchy of glutathione peroxidases (Wingler et al., 1999). It was suggested that GPX2 acts as a barrier against absorption of ingested hydroperoxides and plays a role in the prevention of intestinal inflammation (Esworthy et al., 2005). In contrast, the mRNA expression of the extracellular GPX3 and the phospholipid hydroperoxide glutathione peroxidase GPX4 that protects cells against membrane lipid peroxidation was down-regulated in the same intestinal section. Similarly, the expression of SOD3, an antioxidant enzyme that catalyzes the dismutation of superoxide into oxygen and hydrogen peroxide, was also decreased by the ingestion of DON. These results are in agreement with numerous studies reporting that DON promotes the generation of indicating an induction of reactive oxygen species (ROS) production and modulated, in vitro and in vivo, antioxidant enzyme activities including SOD and GPX (Dinu et al., 2011; Pestka, 2007; Pestka and Smolinski, 2005; Wu et al., 2014a). The up-regulation of the major intestinal antioxidant and anti-inflammatory enzyme GPX2 clearly reveals that DON supplementation has induced oxidative and inflammatory conditions in the epithelium of the ileum section. They are also supporting recent results indicating that increased myeloperoxidase levels and enlargement of Peyer's patches was observed in mice topically treated with DON, suggesting infiltration of inflammatory cells in the intestinal tissue even if DON is not orally administered (Mishra et al., 2014).

On the other hand, down-regulation of the mRNA expression of the principal extracellular antioxidants GPX3 and SOD3 likely suggests that DON did not induce oxidative stress in the ileal lumen. Impaired or increased expression of SOD and different GPX genes could be related to the nature of the tissue and time exposure to DON (Mishra et al., 2014; Wu et al., 2014a). For instance, dietary exposure of broilers to DON and zearalenone for two weeks results in a significant decrease in hepatic GPX activity, whereas activities of blood GPX and plasma gamma-glutamyltransferase increase (Borutova et al., 2008). Studies conducted with different cell lines also revealed that SOD and GPX activities are either increased or decreased after DON exposure in a time dependent manner (Dinu et al., 2011; Li et al., 2014). Modes of DON action are still to be elucidated but impaired antioxidant status of cell and increased production of ROS induced by DON may induce cell damage leading to apoptosis as observed previously in in vitro studies with different types of cells including T cells, B-cells and intestinal epithelial cells (Krishnaswamy et al., 2010; Pestka, 2007). In this study, reduction of $B C L 2$ gene expression, an anti-apoptotic gene that prevents cell death (Thomadaki and Scorilas, 2006), was observed in the ileum. These results suggest that DON through increased production of inflammatory cytokines and ROS and modulation in gene expression of antioxidant enzymes impaired intestinal mucosal health and may increase apoptosis in intestinal tissue of pigs fed DON contaminated feed.

In pigs fed DON contaminated diet, the genes coding for claudins and occludin, main proteins of the tight junctions (Förster, 2008) and markers of intestinal integrity, were also found to be reduced in the ileum. These in vivo results are supporting previous in vitro observations (Pinton et al., 2009), indicating that alterations of transepithelial electrical resistance and paracellular permeability to $4 \mathrm{kDa}$ dextran and to pathogenic Escherichia coli across intestinal porcine epithelial cell line monolayers were associated with a specific reduction in the expression of claudins. The mechanism is still unclear but it has been shown that DON exposure, through the activation of phosphoinositide 3-kinase/AKT (protein kinase B) and mitogenactivated protein kinase (MAPK) signaling pathways (Mishra et al., 2014; Pestka, 2007), is capable to modulate inflammatory response and to influence the expression of tight junction protein such as claudin-4 protein (Pinton et al., 2010).

Cytokines such as TNF- $\alpha$, IL1 and IFNG are also capable of activating MAPK (Prickett and Brautigan, 2007; Valledor et al., 2008). Moreover, intestinal barrier dysfunction mediated by IFNG and TNF- $\alpha$ has been related to a displacement of claudin and occludin proteins from membrane microdomains of tight junctions (Bruewer et al., 2003; Li et al., 2008). In addition, we noted that the expression of vimentin-like gene was decreased. Vimentin protein is expressed in myofibroblast of intestinal sub-epithelial layer and play supportive roles, like promoting epithelial regrowth and enhancing barrier function during stress and inflammatory response (Beltinger et al., 1999; Lahar et al., 2011). These results suggest that ingestion of DON may also disrupt intestinal barrier function through the induction of inflammatory cytokines, activation of Th1 type immune response in the intestinal mucosa and decrease of tight junction and myofibroblast proteins.

A recent study realized in mice indicated that DON and other contaminants naturally-occurring in feed such as DON congeners are capable to elicit aberrant mRNA up-regulation of cytokines associated with acute and chronic trichothecene toxicity (Wu et al., 2014b). Other studies also revealed that DON naturally contaminated wheat grains, due to the presence of other toxins and microbial antigens, are more toxic than pure DON (Prelusky et al., 1994; Rotter et al., 1996). These observations suggest that the influence of DON on gut barrier function and inflammatory response could be exacerbated by increased epithelial permeability to intestinal and dietary microbial antigens and toxins such as LPS and DON congeners.

In summary, the present data strongly suggest that ingestion of DON naturally contaminated feed impaired intestinal barrier and immunological functions by modulating expression of genes coding for proteins involved in tight junctions, tissue remodeling, inflammatory reaction, oxidative stress reaction and immune response. Further investigation is needed to evaluate the effects of DON contaminated feed on alteration of intestinal defenses and consequences on resistance to enteric infections in swine and other species.

\section{Authors' contributions}

ML, KD and CS wrote the manuscript. KD also carried out the gene expression analysis and CS and VP carried out the immunological assays. KL participated in plasma measurement and provided technical help. VP, CS, KD, KL, ML, CAG and YC participated in animal sampling and laboratory analyses. JL contributed in the selection of enzyme genes involved in oxidative reaction and in writing the manuscript. The study was conceived by ML, YC, FG, and CAG, and 
all of them were involved in the coordination of research activities and writing the manuscript. All authors read and approved the final manuscript.

\section{Conflict of interest}

The authors declare that there are no conflicts of interest.

\section{Transparency document}

The Transparency document associated with this article can be found in the online version.

\section{Acknowledgements}

The authors gratefully thank the Canadian Swine Research and Development Cluster (project \# 1014) for funding this project. C Savard was a recipient of postdoctoral fellowships from the Canadian Swine Health Board (CSHB) and Fonds de recherche du Québec - Nature et technologies (FRQNT). V Pinilla received scholarships from Innovagrains Network and CRIPA. K. Deschene received postdoctoral fellowships in Canadian Government Laboratories from NSERC. The authors would like also to thank Steve Methot for statistical analyses of data.

\section{References}

Abramson, D., Mills, J.T., Marquardt, R.R., Frohlich, A.A., 1997. Mycotoxins in fungal contaminated samples of animal feed from western Canada, 1982-1994. Can. J. Vet. Res. 61, 49-52.

Accensi, F., Pinton, P., Callu, P., Abella-Bourges, N., Guelfi, J.F., Grosjean, F., et al., 2006. Ingestion of low doses of deoxynivalenol does not affect hematological, biochemical, or immune responses of piglets. J. Anim. Sci. 84, 1935-1942.

Andretta, I., Kipper, M., Lehnen, C.R., Hauschild, L., Vale, M.M., Lovatto, P.A., 2012 Meta-analytical study of productive and nutritional interactions of mycotoxins in growing pigs. Animal 6, 1476-1482.

Asnagli, H., Murphy, K.M., 2001. Stability and commitment in T helper cell development. Curr. Opin. Immunol. 13, 242-247.

Belardelli, F., Ferrantini, M., 2002. Cytokines as a link between innate and adaptive antitumor immunity. Trends Immunol. 23, 201-208.

Beltinger, J., McKaig, B.C., Makh, S., Stack, W.A., Hawkey, C.J., Mahida, Y.R., 1999. Human colonic subepithelial myofibroblasts modulate transepithelial resistance and secretory response. Am. J. Physiol. 277, C271-C279.

Bergsjø, B., Langseth, W., Nafstad, I., Jansen, J.H., Larsen, H.J.S., 1993. The effects of naturally deoxynivalenol-contaminated oats on the clinical condition, blood parameters, performance and carcass composition of growing pigs. Vet. Res. Commun. 17, 283-294.

Bimczok, D., Döll, S., Rau, H., Goyarts, T., Wundrack, N., Naumann, M., et al., 2007. The Fusarium toxin deoxynivalenol disrupts phenotype and function of monocyte-derived dendritic cells in vivo and in vitro. Immunobiology 212 , 655-666.

Borutova, R., Faix, S., Placha, I., Gresakova, L., Cobanova, K., Leng, L., 2008. Effects of deoxynivalenol and zearalenone on oxidative stress and blood phagocytic activity in broilers. Arch. Anim. Nutr. 62, 303-312.

Bracarense, A.P., Lucioli, J., Grenier, B., Drociunas Pacheco, G., Moll, W.D., Schatzmayr, G., et al., 2012. Chronic ingestion of deoxynivalenol and fumonisin, alone or in interaction, induces morphological and immunological changes in the intestine of piglets. Br. J. Nutr. 107, 1776-1786.

Bruewer, M., Luegering, A., Kucharzik, T., Parkos, C.A., Madara, J.L., Hopkins, A.M., et al., 2003. Proinflammatory cytokines disrupt epithelial barrier function by apoptosis-independent mechanisms. J. Immunol. 171, 6164-6172.

Calvo, A.M., 2005. Mycotoxins. In: Dabrowski, W.M., Sikorsk, Z.E. (Eds.), Toxins in Food. CRC Press, Boca Raton, FL.

Canadian Council on Animal Care, 2009. Guidelines on the Care and Use of Farm Animals in Research, Teaching and Testing. Canadian Council on Animal Care, Ottawa, ON, Canada.

CAST (Ed.), 2003. Mycotoxins: Risks in Plant, Animal and Human Systems. Council for Agricultural Sciences and Technology, Ames, IA.

Chen, F., Ma, Y., Xue, C., Ma, J., Xie, Q., Wang, G., et al., 2008. The combination of deoxynivalenol and zearalenone at permitted feed concentrations causes serious physiological effects in young pigs. J. Vet. Sci. 9, 39-44.

Chu, F.F., Doroshow, J.H., Esworthy, R.S., 1993. Expression, characterization, and tissue distribution of a new cellular selenium-dependent glutathione peroxidase, GSHPx-GI. J. Biol. Chem. 268, 2571-2576.

Dinu, D., Bodea, G.O., Ceapa, C.D., Munteanu, M.C., Roming, F.I., Serban, A.I., et al., 2011. Adapted response of the antioxidant defense system to oxidative stress induced by deoxynivalenol in Hek-293 cells. Toxicon 57, 1023-1032.
Doll, S., Danicke, S., Ueberschar, K.H., Valenta, H., Schnurrbusch, U., Ganter, M., et al., 2003. Effects of graded levels of Fusarium toxin contaminated maize in diets for female weaned piglets. Arch. Tierernahr. 57, 311-334.

Drochner, W., Schollenberger, M., Piepho, H.P., Gotz, S., Lauber, U., Tafaj, M., et al., 2004. Serum IgA-promoting effects induced by feed loads containing isolated deoxynivalenol (DON) in growing piglets. J. Toxicol. Environ. Health A 67, 1051-1067.

Étienne, M., 2007. Effets biologiques et physiologiques d'une mycotoxine, le déoxynivalénol (DON), chez le porc. Journées Recherche Porcine 407-418.

Esworthy, R.S., Yang, L., Frankel, P.H., Chu, F.F., 2005. Epithelium-specific glutathione peroxidase, Gpx2, is involved in the prevention of intestinal inflammation in selenium-deficient mice. J. Nutr. 135, 740-745.

Förster, C., 2008. Tight junctions and the modulation of barrier function in disease. Histochem. Cell Biol. 130, 55-70.

Goodband, B., Tokach, M., Dritz, S., Derouchey, J., Woodworth, J., 2014. Practical starter pig amino acid requirements in relation to immunity, gut health and growth performance. J. Anim. Sci. Biotechnol. 5, 12.

Goyarts, T., Danicke, S., 2005. Effects of deoxynivalenol (DON) on growth performance, nutrient digestibility and DON metabolism in pigs. Mycotoxin Res. 21, 139-142.

Goyarts, T., Dänicke, S., Tiemann, U., Rothkötter, H.-J., 2006. Effect of the Fusarium toxin deoxynivalenol (DON) on IgA, IgM and IgG concentrations and proliferation of porcine blood lymphocytes. Toxicol. In Vitro 20, 858-867.

Grosjean, F., Callu, P., Pinton, P., Skiba, F., Barrier-Guillot, B., Oswald, I.P., 2003. Quantification des effets de la consommation de déoxynivalénol (DON) par le porcelet sevré. Journées Recherche Porcine 443-450.

Grosjean, F., Pinton, P., Callu, P., Oswald, I.P., 2007. Effets de la consommation par le porcelet sevré d,aliment contenant du blé naturellement fusarié. Journées Recherche Porcine 427-428.

Krishnaswamy, R., Devaraj, S.N., Padma, V.V., 2010. Lutein protects HT-29 cells against Deoxynivalenol-induced oxidative stress and apoptosis: prevention of NF- $\kappa$ B nuclear localization and down regulation of NF- $\kappa B$ and Cyclo-Oxygenase-2 expression. Free Radic. Biol. Med. 49, 50-60.

Lahar, N., Lei, N.Y., Wang, J., Jabaji, Z., Tung, S.C., Joshi, V., et al., 2011. Intestinal subepithelial myofibroblasts support in vitro and in vivo growth of human small intestinal epithelium. PLoS ONE 6, e26898.

Li, D., Ye, Y., Lin, S., Deng, L., Fan, X., Zhang, Y., et al., 2014. Evaluation of deoxynivalenol-induced toxic effects on DF-1 cells in vitro: cell-cycle arrest, oxidative stress, and apoptosis. Environ. Toxicol. Pharmacol. 37, 141-149.

Li, Q., Zhang, Q., Wang, M., Zhao, S., Ma, J., Luo, N., et al., 2008. Interferon- $\gamma$ and tumor necrosis factor- $\alpha$ disrupt epithelial barrier function by altering lipid composition in membrane microdomains of tight junction. Clin. Immunol. 126, 67-80.

Mishra, S., Dwivedi, P.D., Pandey, H.P., Das, M., 2014. Role of oxidative stress in deoxynivalenol induced toxicity. Food Chem. Toxicol. 72, 20-29.

Moore, C.J., Blaney, B.J., Spencer, R.A., Dodman, R.L., 1985. Rejection by pigs of mouldy grain containing deoxynivalenol. Aust. Vet. J. 62, 60-62.

National Swine Nutrition Guide, 2010. US Pork Excellence Center, Iowa State University Extension Service, Ames, USA.

Overnes, G., Matre, T., Sivertsen, T., Larsen, H.J., Langseth, W., Reitan, L.J., et al., 1997. Effects of diets with graded levels of naturally deoxynivalenol-contaminated oats on immune response in growing pigs. Zentralbl. Veterinarmed. A 44, 539-550.

Pestka, J.J., 2007. Deoxynivalenol: toxicity, mechanisms and animal health risks. Anim. Feed Sci. Technol. 137, 283-298.

Pestka, J.J., Smolinski, A.T., 2005. Deoxynivalenol: toxicology and potential effects on humans. J. Toxicol. Environ. Health B Crit. Rev. 8, 39-69.

Pinton, P., Accensi, F., Beauchamp, E., Cossalter, A.M., Callu, P., Grosjean, F., et al., 2006. Effets de la consommation d'aliment naturellement contaminé par déoxynivalénol (DON) sur la réponse vaccinale du porc. Journées Recherche Porcine 399-406.

Pinton, P., Accensi, F., Beauchamp, E., Cossalter, A.M., Callu, P., Grosjean, F., et al., 2008. Ingestion of deoxynivalenol (DON) contaminated feed alters the pig vaccinal immune responses. Toxicol. Lett. 177, 215-222.

Pinton, P., Nougayrede, J.P., Del Rio, J.C., Moreno, C., Marin, D.E., Ferrier, L., et al., 2009 The food contaminant deoxynivalenol, decreases intestinal barrier permeability and reduces claudin expression. Toxicol. Appl. Pharmacol. 237, 41-48.

Pinton, P., Braicu, C., Nougayrede, J.P., Laffitte, J., Taranu, I., Oswald, I.P., 2010. Deoxynivalenol impairs porcine intestinal barrier function and decreases the protein expression of claudin-4 through a mitogen-activated protein kinasedependent mechanism. J. Nutr. 140, 1956-1962.

Prelusky, D.B., Rotter, B.A., Rotter, R.G., 1994. Toxicology of mycotoxins. In: Miller, J.D., Trenholm, H.L. (Eds.), Mycotoxins in Grain: Compounds Other Than Aflatoxin. Eagan Press, St. Paul, MN, pp. 359-403.

Prickett, T.D., Brautigan, D.L., 2007. Cytokine activation of p38 mitogen-activated protein kinase and apoptosis is opposed by alpha-4 targeting of protein phosphatase 2A for site-specific dephosphorylation of MEK3. Mol. Cell. Biol. 27, 4217-4227.

Rotter, B.A., Thompson, B.K., Rotter, R.G., 1994. Optimization of the mouse bioassay for deoxynivalenol as an alternative to large animal studies. Bull. Environ. Contam. Toxicol. 53, 642-647.

Rotter, B.A., Prelusky, D.B., Pestka, J.J., 1996. Toxicology of deoxynivalenol (vomitoxin) J. Toxicol. Environ. Health 48, 1-34.

SAS Institute Inc., 2009. SAS Statistical Analysis System. Release 9.2. SAS Institute, Inc., Cary, NC, USA.

Swamy, H.V., Smith, T.K., MacDonald, E.J., Karrow, N.A., Woodward, B., Boermans, H.J., 2003. Effects of feeding a blend of grains naturally contaminated with Fusarium mycotoxins on growth and immunological measurements of starter pigs, and the efficacy of a polymeric glucomannan mycotoxin adsorbent. J. Anim. Sci. 81, 2792-2803. 
Szabo, S.J., Sullivan, B.M., Peng, S.L., Glimcher, L.H., 2003. Molecular mechanisms regulating Th1 immune responses. Annu. Rev. Immunol. 713-758.

Thomadaki, H., Scorilas, A., 2006. BCL2 family of apoptosis-related genes: functions and clinical implications in cancer. Crit. Rev. Clin. Lab. Sci. 43, 1-67.

Valledor, A.F., Sánchez-Tilló, E., Arpa, L., Park, J.M., Caelles, C., Lloberas, J., et al., 2008. Selective roles of MAPKs during the macrophage response to IFN- $\gamma$. J. Immunol. 180, 4523-4529.

Vesonder, R.F., Ciegler, A., Rogers, R.F., Burbridge, K.A., Bothast, R.J., Jensen, A.H., 1978. Survey of 1977 crop year preharvest corn for vomitoxin. Appl. Environ. Microbiol. 36, 885-888.

Walsh, K.P., Mills, K.H.G., 2013. Dendritic cells and other innate determinants of T helper cell polarisation. Trends Immunol. 34, 521-530.

Wingler, K., Bocher, M., Flohe, L., Kollmus, H., Brigelius-Flohe, R., 1999. mRNA stability and selenocysteine insertion sequence efficiency rank gastrointestinal glutathione peroxidase high in the hierarchy of selenoproteins. Eur. J. Biochem. 259, 149-157.
Wu, Q.H., Wang, X., Yang, W., Nüssler, A.K., Xiong, L.Y., Kuča, K., et al., 2014a. Oxidative stress-mediated cytotoxicity and metabolism of T-2 toxin and deoxynivalenol in animals and humans: an update. Arch. Toxicol. 88, 1309-1326.

Wu, W., He, K., Zhou, H.R., Berthiller, F., Adam, G., Sugita-Konishi, Y., et al., 2014b. Effects of oral exposure to naturally-occurring and synthetic deoxynivalenol congeners on proinflammatory cytokine and chemokine mRNA expression in the mouse. Toxicol. Appl. Pharmacol. 278, 107-115.

Xiao, H., Wu, M.M., Tan, B.E., Yin, Y.L., Li, T.J., Xiao, D.F., et al., 2013. Effects of composite antimicrobial peptides in weanling piglets challenged with deoxynivalenol: I. Growth performance, immune function, and antioxidation capacity. J. Anim. Sci. $91,4772-4780$

Zhang, J., Tang, Z., Wang, N., Long, L., Li, K., 2012. Evaluating a set of reference genes for expression normalization in multiple tissues and skeletal muscle at different development stages in pigs using quantitative real-time polymerase chain reaction. DNA Cell Biol. 31, 106-113. 